\title{
JOB SATISFACTION AND ON-THE-JOB SEARCH: A THEORETICAL AND EMPIRICAL APPROACH
}

\author{
Carlos Gamero ${ }^{1}$ \\ Universidad de Málaga
}

Received 1 October 2008; accepted 30 September 2009

\section{Resumen}

Este artículo presenta un modelo teórico de búsqueda de empleo desde el empleo (BDE) basado en la maximización intertemporal de la utilidad del trabajo. El marco teórico esbozado supone una traducción en términos de utilidad del planteado por Burdett (1978), basado en la maximización de la renta laboral esperada. El nuevo modelo deriva dos niveles de utilidad de reserva, en lugar de dos salarios de reserva. Este resultado permite vincular la verosimilitud de BDE con el nivel de satisfacción laboral. El modelo teórico es contrastado empíricamente usando una encuesta representativa de la población ocupada en España (ECVT, 2004).

Palabras clave: Satisfacción laboral, movilidad laboral, búsqueda de empleo desde el empleo.

Clasificación JEL: J28, J62, J64.

\begin{abstract}
This paper presents a theoretical model of on-the-job search (OJS) based on the maximization of the intertemporal utility of work. The theoretical framework outlined is a translation in terms of utility of that proposed by Burdett (1978), which is based on the maximization of expected labour income. The new model derives two levels of reservation utility, instead of two reservation wages. This result allows linking the likelihood of OJS with the level of job satisfaction. The theoretical model is empirically tested using a representative survey of the wage earner population in Spain (ECVT, 2004).
\end{abstract}

Key words: Job satisfaction, labour mobility, on-the-job search.

JEL Classification: J28, J62, J64.

\footnotetext{
1 Correspondence to: gamero@uma.es. The author would like to thank helpful comments from the editor and an anonymous referee. This research has been possible with the financial support from 'Ministerio de Ciencia e Innovación' (research project SEJ200768045-C02-01/ECON) and from 'Fundación Centro de Estudios Andaluces' (research project PRY116/09). The usual disclaimer applies.
}

(C) Revista de Economía Laboral 
Gamero / Revista de Economía Laboral 6 (2009), 35-54

\section{Introduction}

Since Freeman's work (1978), the economic literature has consistently identified job (dis)satisfaction as a good predictor of effective labour mobility-that is, quits (Clark et al., 1998; Lévy-Garboua et al., 2001). Furthermore, some evidence confirms the negative correlation between job satisfaction and intention to quit (Shields and Ward, 2001; Souza-Poza and Henneberger, 2001). To the best of our knowledge, academics interested in job satisfaction have paid little attention to onthe-job search, one of the most objective forms of potential mobility. However, it seems likely that highly satisfied workers exhibit a lower propensity to inspect the labour market for new job opportunities.

In the case of the Spanish labour market, and based on the available sources of information, it is clear that on-the-job search is not an anecdotal fact at all. According to European Community Household Panel Survey (PHOGUE) and pooled data for the period 1994-1997, more than $12 \%$ of workers were looking for a new job. According to the information from the Encuesta de Calidad de Vida y de Trabajo (ECVT) for the year 2004, that figure continues to be high (9.6\%).

Based on the neoclassical theory of labour supply, the scarce onthe-job search theories (Barron y McCafferty, 1977; Burdett, 1978; Seater, 1979; Benhabib y Bull, 1983; Mortensen, 1986) assume that wage is the fundamental attractiveness of a job and, as a consequence, the main variable that drives mobility. It supposes that the individual is pursuing income maximization, and it implicitly implies that non-pecuniary job characteristics do not explain behaviour in the labour market. On these bases, the main result obtained is an optimal search strategy that exhibits the property of reservation wage.

However, for the great majority of workers, a job represents more than an exchange of leisure time for money. Around this idea, several theoretical and empirical investigations have explicitly highlighted the decisive role that non-pecuniary job attributes play in job quits. ${ }^{2}$ All of them share with wage mobility models the assumption that workers are rational agents who derive their optimal strategy of behaviour from a maximization problem. The difference lies in the fact that the function to be maximized is written down in terms of utility of work, which embraces all job characteristics. As far as we know, the literature focusing

\footnotetext{
2 Works that investigate the link between job satisfaction and labor mobility, mentioned at the beginning of this section, share this point of view. Viscusi (1979), Bartel (1982) and Akerlof et al. (1988) are examples of alternative ways of introducing the nonpecuniary job characteristics in quits equations.
} 
specifically on the on-the-job search does not offer any theoretical formalization that matches the previous focus, although some empirical works share its ideas (Van Ophem, 1991; Hughes and McCormick, 1985, Delfgaauw, 2007).

This paper is structured as follows. Section 2 presents a theoretical model that enlarges the pecuniary perspective by defining the problem of intertemporal optimization in terms of utility of work. This utility of work depends on both the pecuniary and non-pecuniary characteristics of employment. This enables us to link job satisfaction judgements to the decision to conduct an on-the-job search. In Section 3 job satisfaction is presented as an index of subjective well-being at work and its determinants are empirically investigated. The empirical relationship between job satisfaction and on-the-job search is addressed in section 4, trying to evaluate the role of job satisfaction in explaining that kind of behaviour. Finally, section 5 draws some conclusions and presents future work proposals.

\section{An on-the-job search for utility model}

In general, neoclassical economics defines paid work as the activity that gives people the necessary means to survive and enjoy life. The traditional microeconomic analysis explains the exchange of leisure for work on the basis that consumption goods, which can be achieved mostly through labour income, provide greater utility than leisure. In other words, individuals obtain utility from work only indirectly through the consumption that the monetary compensation for work allows them.

Adopting this approach has important implications for economic analysis of the labour market. To consider work as "evil" or penalty denies the possibility that individuals derive utility from work directly. Accordingly, the assessment of the relative quality of jobs may be made taking into account only their buying power. That grants maximum weight to wages in the management of individual decisions in the labour market.

It is sometimes forgotten that this is only an explicative model of the behaviour in the labour market, and as a model, it is a simplification of reality or, at least, it is only fully applicable to very particular situations, probably the ones that took place in the historical moment in which those ideas came to life. However, the actual reality requires a review of the significance that the orthodox economic theory confers to work, so that instead of a production factor, placed at the same level as land or capital, it must be considered as a product itself. That is, as a good 
Gamero / Revista de Economía Laboral 6 (2009), 35-54

capable of providing utility due to its inherent characteristics. This makes possible to talk about the quality of work experiences and jobs, and thus opens the door to welfare concern in the workplace.

This section presents an on-the-job search model that implicitly recognizes the non-pecuniary job characteristics in the individual's decision making process. Its general framework entails a simple translation in terms of utility of the one outlined by Burdett's (1978), so individuals are not wage searchers but utility searchers. The main implication of this new interpretation is that workers base their on-thejob-search decision on a comparison between the total utility provided by their current job and a certain level of reference utility (reservation utility). As it will be shown later on, this allows us to relate the decision to search for a new job to the level of satisfaction that the worker gets from his current job.

The main assumption of our model is that each job is thought to have a number of both extrinsic aspects (work conditions, remuneration) and intrinsic ones (the variety of job tasks, the opportunity for personal control, the possibility of utilizing one's skills, networking opportunities, etc.) from which workers derive utility. The different mixture of such aspects leads to a differentiated job. Thus, two different combinations of characteristics for the same job may be viewed by the worker as equally attractive, provided that a low content in one desirable aspect is compensated by an increase in another. By considering the mix of properties, the intrinsic qualities of individual jobs can be incorporated into the analysis.

From now on, it is assumed that a worker's finite working life can be divided into $T$ periods so a worker about to begin period $t$ of his working life will be said to be of (working) age $t$. It is explicitly assumed that individuals are motivated to act in order to maximize the intertemporal utility derived from their working activity (expected total utility, hereafter). It is also assumed that any job offer received by an individual in every period of his finite live is determined by a level $u$ ' of instantaneous utility, which is time invariant and interpreted as cardinal. Each worker has some idea of the utility levels of the jobs that he believes are available to him in the labour market. Also, it is assumed that this individual's information on the available levels of utility can be characterized by a distribution function of utility levels, $F(u)$, which is time invariant and possibly specific to each individual. A worker who accepts an offer $u$ 'works receiving that utility per period until he retires or quits. If an offer is rejected, it is assumed that the worker will be able to accept it in a later period. 
In order to maximize the expected total utility of the labour activity, in any period individual can select one of the following three options:

- Option 1: Search but non work (S-NW),

- Option 2: Search and work (S-W),

- Option 3: Non search and work (NS-W).

In any period, search activity, which implies the reception of one job offer, has a cost $u_{c}$ expressed in terms of utility. This cost depends on the search method adopted. We assume $u_{c}(1)<u_{c}(2)$ so that the utility cost of looking for a job while employed must be greater then the utility cost while unemployed. ${ }^{3}$ An unemployed worker who attempts to obtain a job in a period is eligible for unemployment insurance payment $b$ in that period. This payment, if receipt in period $t$, provides to individual an utility equal to $u(b)$ in that period. The temporary preference for utility is represented by a constant rate $\rho$ that defines the discount factor of the utilities stream as $\beta=1 /(1+\rho)$.

Under this assumptions set, let $\varphi_{1 \mathrm{t}}\left[u^{\prime}, b, c(1)\right], \varphi_{2 \mathrm{t}}\left[u^{\prime}, c(2)\right]$, and $\varphi_{3 t}\left(u^{\prime}\right)$, respectively, be the total utility of the labour activity of the individual associated to the offer received, $u^{\prime}$, if he chooses options 1,2 , or 3 for the next period. The worker will choose in one period the option that provides the greatest expected total utility (net of search disutility). The maximum expected utility for a worker $t$ years of age who has received a maximum offer of utility $u^{\prime}$ to date is denoted by

$$
\psi\left(u^{\prime}, t\right)=\max \left\{\varphi_{1 t}\left[u^{\prime}, b, c(1)\right], \varphi_{2 t}\left[u^{\prime}, c(2)\right], \varphi_{3 t}\left(u^{\prime}\right)\right\}
$$

As the same manner as Burdett (1978) did, it can be demonstrated that if the cost (disutility) associated with on-the-job search is not too high, the individual's best strategy will be to select two reservation utilities, $u^{*}$ and $u_{t}^{* *}$, with $u^{*}<u_{t}^{* * *}$, which can be written as:

$$
\begin{aligned}
& u^{*}=u(b)+u_{c}(1)-u_{c}(2) \\
& u_{c}(2)=-\beta \int_{u_{t}^{* *}}^{\infty}\left\{\psi(u, t+1)-\psi\left(u_{t}^{* *}, t+1\right)\right\} f(u) d u
\end{aligned}
$$

where $\psi(u, t)$ represents the maximum expected utility for a worker $t$ years of age who has received a maximum offer of total utility $u$ to date. Therefore, an unemployed worker will accept any offer if and only if its associated utility is at least equal to $u^{*}$. However, if that utility is acceptable but lower than $u_{t}^{* *}$, the individual will continue looking for

\footnotetext{
${ }^{3}$ For example, the cost of search when employed may include loss of earnings while searching.
} 
another job while employed. The worker will accept any offer with utility greater than $u_{t}^{* *}$, and he will not look for another job while employed.

It is important to notice that, although the utility level associated to any job offer depends on the specific mix of characteristics that the offered job has, from a worker's perspective, all relevant information about a job is summarized in her utility function. Therefore, job search can be viewed as "search for utility". In Burdett's (1978) model, workers receive wage offers and maximize the expected present value of their wage stream. Similarly, in our utility search model, workers receive utility offers and maximize the expected present value of the utility stream. Mathematically, the two models, and hence their solutions, are identical. The optimal search behaviour in Burdett's (1978) on-the-job search model is a two reservation wages strategy. Equivalently, the optimal search behaviour in our utility on-the-job search model is a two reservation utility strategy. ${ }^{4}$

The main implication of our model is that the on-the-job search decision is based on the quality of the current job relative to that of other jobs available in the market. That difference in quality depends not only on the characteristics of the current job but also on those of the job that the worker expects to obtain by searching. In this context, the empirical investigation faces serious limitations due to the lack of available information. Very few labour surveys include workers' evaluations of their job characteristics. Unfortunately, it is even more difficult to find a database that contains the characteristics that they believe that are available in the marketplace.

The referred limitations can be overcomes by introducing job satisfaction judgments in our on-the-job search model. Any job satisfaction judgment can be understood as an ordinal index of subjective well-being at work, which is defined as the comparison between the total utility that an individual expects to obtain from his current job and the total utility that his reference or "ideal" job would have. For each worker, this reference job is the hypothetical one that exhibits the combination of wage and nonwage characteristics that would provide him the maximum expected total utility.

Figure 1 helps us to clarify the theoretical connection between job satisfaction judgements and on-the-job search decision. It presents the intervals of feasibility for options 1,2 , and 3 that are identified by $u^{*}$ and

\footnotetext{
${ }^{4}$ Gorgens (2002) also shares our utility approach. In this paper, a general model of job search is outlined where workers have preferences defined over both wage and nonwage characteristics. There, the focus is on search from unemployment, so only one reservation utility is derived.
} 
$u_{t}^{* *}$ on the line of the expected total utility of jobs (TU). When a worker declares himself fully satisfied with his job, he considers that this job has the characteristics of his "ideal" job and, therefore, that any other job would provide less expected total utility than his current one. Logically, in such case, there are no incentives to develop search activities while employed. In the opposite case, when a worker declares complete dissatisfaction, the total utility that he expects to obtain from his current employment is the minimum one among all acceptable jobs. In this case, the worker has incentives to search while being employed. Therefore, the model predicts a negative relationship between the likelihood of on-the-job search and the declared level of job satisfaction.

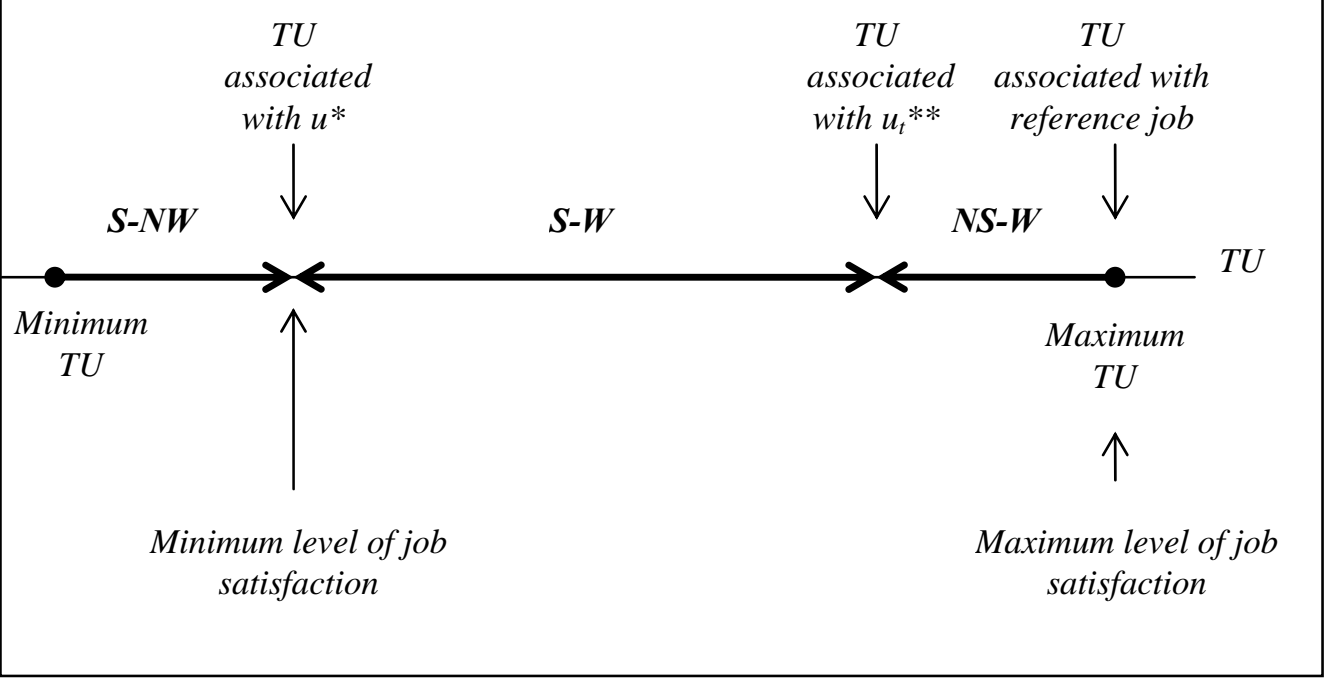

Figure 1. Job satisfaction and on-the-job search decision

\section{Job satisfaction as an index of subjective well- being at work}

Any job satisfaction judgment can be understood as an ordinal index of subjective well-being at work $\left(S W W_{i}\right)$, which is unobservable. Following Gamero (2007), $S W W_{i}$ is defined as the comparison between the 
total utility that an individual expects to obtain from his current job and the total utility that his reference or "ideal" job would have. For each worker, this ideal job, if occupied, would provide him the maximum expected total utility. Formally, it is assumed that the job occupied by individual $i\left(e_{i}\right)$ is described by $K$ components or facets: one of them representing the wage rent and the rest accounting for the non-pecuniary job characteristics:

$$
e_{i}=\left\{z_{i, k}\right\}_{k=1, \ldots, K}
$$

With each of those components, an individual summarizes the past, present and future results of his job in respect to one of its specific characteristics. Similarly, his reference job $\left(e_{i}^{*}\right)$ is given by:

$$
e_{i}^{*}=\left\{z_{i, k}^{*}\right\}_{k=1, \ldots, K}
$$

It is also assumed that individual $i$ has at least some idea on the expected total utility (TU) that job provides and, specifically, $e_{i}$ and $e_{i}^{*}$. Expected total utility is presumed to be an increasing function on its arguments. ${ }^{5}$ Under these conditions, the subjective wellbeing derived from his work $\left(S W W_{i}\right)$, is given by the difference between the expected total utilities associated to these two jobs, i.e.:

$$
S W W_{i}=T U\left(e_{i}\right)-T U\left(e_{i}^{*}\right)
$$

Taking into account [4] and [5] and assuming linearity for $T U(\cdot)$, it is straightforward to derive the following expression for $S W W_{i}$ :

$$
S W W_{i}=\gamma_{1}\left[T U_{1}\left(z_{i 1}\right)-T U_{1}\left(z_{i 1}^{*}\right)\right]+\gamma_{2}\left[T U_{2}\left(z_{i 2}\right)-T U_{2}\left(z_{i 2}^{*}\right)\right]+\cdots+\gamma_{K}\left[T U_{K}\left(z_{i K}\right)-T U_{K}\left(z_{i K}^{*}\right)\right][7]
$$

where each $\left[T U_{k}\left(z_{i k}\right)-T U_{k}\left(z_{i k}{ }^{*}\right)\right]$ term, with $k=1, \ldots, K$, indicates the relative quality of the job actually occupied by individual $i$ in relation to its $k$-th job characteristic, and coefficient $\gamma_{k}$ represents the weight assigned to that facet on overall wellbeing at work.

Denoting such differentials by $v_{i k}$, the latent regression for job satisfaction variable has the following expression:

$$
S W W_{i}=\gamma_{1} v_{i 1}+\gamma_{2} v_{i 2}+\cdots+\gamma_{K} v_{i K}+\xi_{i}=\gamma^{\prime} v_{i}+\xi_{i}
$$

where $\xi_{i}$ is a random disturbance, independently and identically distributed among individuals as $\mathrm{N}\left(0, \sigma^{2}\right)$. If it is assumed that the scale offered to individuals to declare their satisfaction degree is composed of $J$ +1 levels, from 0 (complete dissatisfaction) to $J$ (highest satisfaction), the

\footnotetext{
${ }^{5}$ It is assumed that non-pecuniary job characteristics are defined in positive sense, i.e., as job amenities.
} 
relationship between the reported scores $\left(s a t_{i}\right)$ and the latent variable is given by:

$$
\begin{array}{ccc}
\text { sat }_{i}=0 & \text { if } & -\infty<S W W_{i} \leq \mu_{0} \\
\text { sat }_{i}=1 & \text { if } & \mu_{1}<S W W_{i} \leq \mu_{2} \\
\vdots & & \vdots \\
\text { sat }_{i}=J & \text { if } & \mu_{J-1}<S W W_{i}<+\infty
\end{array}
$$

where the $\mu$ parameters are the values (thresholds) in variable $S W W_{i}$ dividing its range into several intervals associated to different job satisfaction scores.

The data used in the estimation comes from the ECVT (2004). The analysis focuses exclusively on wage earners since their labour situation assimilates better to the theoretical framework previously described. ECVT (2004) provides extensive information on job characteristics as perceived by workers. ${ }^{6}$ It also asks employees to evaluate their satisfaction with work as a whole on a numerical scale so that the responses provided data for the variable called $s a t_{i}$ in our model. The ten levels that make up the original scale have been grouped into three $(0,1$, 2) as indicated below:

- 0 for unsatisfied workers ( 1 to 4 in the original scale),

- 1 for satisfied workers (5 to 7),

- $\quad 2$ for highly satisfied workers (8 to 10 ).

There are two reasons for doing so. The first is that there is little variability and, in most cases, only few observations in the lowest levels of the initial scale. A second reason is that this removes some of the "noise" in the detailed scale.

Since job satisfaction variable, sat, is ordinarily linked with latent regression given by [8] as indicated in [9], the subsequent econometric analysis is based on a model specially designed for the treatment of this kind of data, in particular, the ordered probit model (see Zavoina and McElvey, 1975).

Estimation of sati from equation [8] faces a severe difficulty since information on total utility differentials by components is needed. Worker's current wage could be used as a proxy of the present value of the wage stream. For all other job features, we will directly use the worker's

\footnotetext{
${ }^{6}$ In general, the questions that allow to obtain these data provide a statement to the respondents (eg, my work is attractive and interesting) and request them to indicate their degree of agreement or disagreement on an ordinal scale of five possible answers. For the purposes of estimation, responses were grouped to construct dichotomous variables. See Gamero (2005), Appendix B, for more details.
} 
subjective valuations of the different characteristics of his job. Doing so, we assume that individuals base their judgement on a particular job characteristic in comparison between the expected total utility they obtain in relation to that characteristic and the expected total utility derived from occupying their reference job. ${ }^{7}$ Therefore, the direct use of such valuations exempt from the imposition of assumptions about the temporal extent of all information used by individuals, both in their retrospective and future assessments, and about their way of combining such information.

As aforementioned, ECVT (2004) provides extensive information on job characteristics as perceived by workers. Our econometric specification includes a large set of control variables that reflect several job facets: pay, working-time-related aspects, job hardness, job content and the level of formal communication, personal relationships in the workplace, future prospects, and job mismatch. It also includes a vector of individual characteristics (gender, age, family composition, and educational level) to capture the impact of personal traits in the overall job valuation. The sample finally selected includes a total of 2,357 individuals. Table A.1 in the Appendix shows the descriptive statistics of all variables included in the model.

Table 1 shows the results of the ordered probit model estimation for job satisfaction on the sample finally selected. The general statistics listed at the bottom point out that the model is significant as a whole, with an acceptable goodness of fit (Pseudo- $\mathrm{R}^{2}=23.19 \%$ ), although a substantial amount of variation remains unexplained. The model correctly predicts the level of satisfaction of $64.8 \%$ of the individuals sampled.

The table shows, first, the estimated coefficients for individual characteristics, followed by those relative to the job occupied, grouped according to the job facet they inform of (income, working time, hardness, content and formal communication, personal relationships, future prospects...). Job mismatch, firm activity and region of residence variables are reported at last place. The regressors noted by (§) contain information on subjective valuations of job aspects and genuinely correspond to the theoretical framework presented above. In general, their coefficients show a high level of significance, supporting the relevance of such information for the analysis of job satisfaction.

\footnotetext{
7 A similar interpretation of the informational content of subjective valuations of job characteristic could be found in Van Ophem (1991).
} 
Table 1. Ordered probit estimation of job satisfaction ${ }^{1}$

\begin{tabular}{|c|c|c|c|}
\hline Variables & Coef. & & M.E. ${ }^{2}$ \\
\hline Male & -0.112 & * & -0.045 \\
\hline Age & -0.056 & $* * *$ & -0.022 \\
\hline $\operatorname{Age}^{\wedge} 2(/ 100)$ & 0.073 & $* * *$ & 0.029 \\
\hline \multicolumn{4}{|l|}{ Family composition: } \\
\hline Couple with children & -0.131 & & -0.052 \\
\hline Couple without children & 0.027 & & 0.011 \\
\hline Single with children & -0.153 & * & -0.061 \\
\hline \multicolumn{4}{|l|}{ Education level: } \\
\hline Primary Education & -0.002 & & -0.001 \\
\hline Lower vocational and technical training & 0.173 & $\wedge$ & 0.069 \\
\hline Upper vocational and technical training & 0.018 & & 0.007 \\
\hline Upper secondary education & -0.103 & & -0.041 \\
\hline Higher education: medium degree & -0.077 & & -0.031 \\
\hline Higher education: superior degree & -0.095 & & -0.038 \\
\hline Others levels & -0.222 & & -0.088 \\
\hline Wage (log. Euros per month) & 0.342 & $* * *$ & 0.136 \\
\hline Working hours (log. number of hours per & -0.424 & $* * *$ & -0.169 \\
\hline \multicolumn{4}{|l|}{ Mismatch in time of work/wage } \\
\hline More time and wage $(\S)$ & -0.176 & ** & -0.070 \\
\hline Less time and wage $(\S)$ & -0.335 & $* * *$ & -0.133 \\
\hline Flexible schedule $(\S)$ & -0.129 & $\wedge$ & -0.051 \\
\hline Commuting time: $>45$ minutes & -0.221 & ** & -0.088 \\
\hline Night work & -0.014 & & -0.006 \\
\hline Part-time job & -0.080 & & -0.032 \\
\hline Physically demanding (§) & -0.071 & & -0.028 \\
\hline Stressful (§) & -0.311 & $* * *$ & -0.124 \\
\hline Pleasant environmental conditions ( () & 0.298 & $* * *$ & 0.118 \\
\hline Attractive task $(\S)$ & 0.475 & $* * *$ & 0.187 \\
\hline Can work independently (§) & 0.230 & $* * *$ & 0.091 \\
\hline Helpful for people $(\S)$ & -0.066 & & -0.026 \\
\hline Can give opinions $(\S)$ & 0.073 & & 0.029 \\
\hline Teamwork & -0.081 & & -0.032 \\
\hline Supervisor/manager & 0.058 & & 0.023 \\
\hline Good relationships with managers $(\S)$ & 0.471 & $* * *$ & 0.186 \\
\hline Good relationships with colleagues $(\S)$ & 0.250 & $* * *$ & 0.099 \\
\hline Promotion prospects $(\S)$ & 0.088 & $\wedge$ & 0.035 \\
\hline \multicolumn{4}{|l|}{ Training mismatch: } \\
\hline Over-training $(\S)$ & -0.400 & $* * *$ & -0.157 \\
\hline Under-training (§) & 0.007 & & 0.003 \\
\hline Previously unemployed & -0.162 & $* * *$ & -0.065 \\
\hline Job tenure & -0.006 & * & -0.002 \\
\hline Job is stable $(\S)$ & 0.520 & $* * *$ & 0.202 \\
\hline Industry dummies (9) & & Yes & \\
\hline Regional dummies (16) & & Yes & \\
\hline$\mu_{1}$ & -1.678 & $* * *$ & \\
\hline$\mu_{2}$ & 0.052 & $* * *$ & \\
\hline Number of observations & & 2357 & \\
\hline Log likelihood ratio test & & 937.14 & \\
\hline Pseudo- $R^{2}(\%)$ & & 21.2 & \\
\hline Obs. correctly classified (\%) & & 64.8 & \\
\hline
\end{tabular}

$1^{* * * / * * /^{*} / \wedge}$ Significant at the $1 \%, 5 \%, 10 \%$ and $15 \%$ level, respectively.

${ }^{2}$ Marginal effects on $\operatorname{Pr}\left(s a t_{i}=2\right)$, calculated according to Greene (1999).

Source: Own calculations from ECVT (2004). 
Gamero / Revista de Economía Laboral 6 (2009), 35-54

The results reproduce some usual findings in the economic literature. Firstly, there is a differential impact by gender in job satisfaction for women (Clark, 1997). Secondly, there is a well-defined profile with a U-shape between age and job satisfaction (Clark et al., 1996) with a minimum of the convex relationship around 38 years. Regarding employment characteristics, the sign of the correlations shown by wage (positive) and number of working hours (negative) are the ones expected. All the coefficients associated to variables indicating subjective valuations of job aspects show the expected signs, being job stability and good relationships with managers those associated to a greatest marginal effect.

\section{Empirical relationship between job satisfaction and on-the-job search}

Based on the assumption that workers try to maximize the intertemporal utility derived from their labour activity, our theoretical model predicts a negative relationship between the declared level of job satisfaction and the likelihood of on-the-job search. This section aims to check the suitability of such a prediction using multivariate analysis techniques. Table 2 shows the empirical relationship between the propensity to search a new job and the declared level of job satisfaction. In general, the figures support the hypothesis that the likelihood of on-thejob search diminishes as job satisfaction increases.

The multivariate analysis of the role that job satisfaction plays in explaining on-the-job search is carried out. We analyze the factors that explain the decision to look for a new job. In this case, the dependent variable is binary ( $y=0$ if there is no search, $y=1$ if search) and a binomial probit model is used. It is important to notice that our source of information (ECVT, 2004) is a survey directed exclusively to employed people, so any possible bias in the estimates associated with sample selection cannot be treated econometrically.

The first column of Table 3 shows the estimates for a basic model for on-the-job search, in which the variables included are of habitual presence in this type of analysis. Table A.2 in the Appendix shows the distribution of on-the-job search according to those characteristics. Jointly considered, the results are commendable. Its figures reflect some of the relationships predicted for wage search theory: negative relationships with age, wage level, job tenure and a positive correlation with number of working hours and commuting time. In this context, job tenure picks up 
the set of wage and nonwage earnings associated with the duration of the labour relationship, which are considered inherent costs to switching jobs, since these earnings are not transferrable among firms. The coefficients associated to other indicators of the quality of job mismatch (divergence with the desired combination of working hours and wage, over-training, previous situation of unemployment) also show statistical significance.

Table 2. Distribution of on-the-job search by level of job satisfaction among wage earners

\begin{tabular}{lrr}
\hline \multicolumn{1}{c}{ Satisfaction level } & N & Search (\%) \\
\hline Original scale & & \\
1 (fully unsatisfied) & 40 & 45.0 \\
2 & 40 & 40.0 \\
3 & 116 & 35.6 \\
4 & 212 & 30.2 \\
5 & 288 & 17.0 \\
6 & 418 & 14.2 \\
7 & 775 & 6.7 \\
8 & 222 & 3.7 \\
9 & 211 & 1.8 \\
10 (fully satisfied) & 2,357 & 3.8 \\
Total & & 10.7 \\
Grouped levels & 231 & 35.1 \\
Unsatisfied (1-4) & 918 & 11.4 \\
Satisfied (5-7) & 1208 & 3.4 \\
Very satisfied (8-10) & 2,357 & 10.7 \\
\hline Total &
\end{tabular}

The largest marginal effect on the search likelihood corresponds to the perception of employment stability: workers that foresee that their labour relationship could end and their utility stream could be disrupt use on-the-job search as a way of avoiding the future unemployment situation or, at least, to reduce the duration of that negative experience. Also, having university studies is associated to a higher propensity to search. Individuals with university degree could decide to accept temporarily less qualified jobs and continue searching, if their labour market is hard due to the considerable increase in the offer. ${ }^{8}$ It could be also a consequence of a higher rate of job offers and/or a higher ability to conduct a search.

${ }^{8}$ See Van Ours and Ridder (1995), Dolado et al. (2000), and Sáez and Rey (2000). 
Table 3. Probit estimation of on-the-job search ${ }^{1}$

\begin{tabular}{|c|c|c|c|c|c|c|}
\hline \multirow{2}{*}{ Variables } & \multicolumn{3}{|c|}{ Estimation (1) } & \multicolumn{3}{|c|}{ Estimation (2) } \\
\hline & Coef. & & M.E. & Coef. & & M.E. \\
\hline Constant & 0.654 & & & 1.461 & & \\
\hline Male & -0.092 & & -0.009 & -0.140 & & -0.012 \\
\hline Age & 0.049 & $\wedge$ & 0.005 & 0.041 & & 0.003 \\
\hline $\operatorname{Age}^{\wedge} 2(/ 100)$ & -0.083 & $* *$ & -0.008 & -0.073 & * & -0.006 \\
\hline \multicolumn{7}{|l|}{ Family composition: } \\
\hline Couple with children & -0.148 & & -0.013 & -0.170 & & -0.012 \\
\hline Couple without children & -0.128 & & -0.012 & -0.113 & & -0.009 \\
\hline Single with children & -0.131 & & -0.012 & -0.182 & & -0.013 \\
\hline \multicolumn{7}{|l|}{ Education level: } \\
\hline Primary Education & -0.008 & & -0.001 & 0.024 & & 0.002 \\
\hline Lower vocational and technical training & 0.008 & & 0.001 & 0.094 & & 0.008 \\
\hline Upper vocational and technical training & 0.045 & & 0.004 & 0.098 & & 0.008 \\
\hline Upper secondary education & -0.085 & & -0.008 & -0.109 & & -0.008 \\
\hline Higher education: medium degree & 0.042 & & 0.004 & 0.107 & & 0.009 \\
\hline Higher education: superior degree & 0.291 & $\wedge$ & 0.033 & 0.379 & * & 0.039 \\
\hline Others levels & -0.292 & & -0.022 & -0.291 & & -0.018 \\
\hline Wage (log. of euros per month) & -0.565 & $* * *$ & -0.054 & -0.420 & $* * *$ & -0.034 \\
\hline Hours of work (log. Number of hours per & 0.289 & * & 0.028 & 0.098 & & 0.008 \\
\hline \multicolumn{7}{|l|}{ Mismatch in time of work/wage combination: } \\
\hline More time and wage & 0.248 & $* *$ & 0.027 & 0.192 & * & 0.017 \\
\hline Less time and wage & 0.101 & & 0.010 & -0.044 & & -0.003 \\
\hline Commuting time: $>45$ minutes & 0.331 & $* *$ & 0.040 & 0.235 & * & 0.023 \\
\hline \multicolumn{7}{|l|}{ Training mismatch: } \\
\hline Over-training & 0.452 & $* * *$ & 0.055 & 0.314 & $* * *$ & 0.030 \\
\hline Under-training & 0.172 & & 0.019 & 0.115 & & 0.010 \\
\hline Previously unemployed & 0.283 & $* * *$ & 0.028 & 0.249 & $* * *$ & 0.021 \\
\hline Job tenure & -0.018 & $* *$ & -0.002 & -0.024 & $* * *$ & -0.002 \\
\hline Job is stable & -0.832 & $* * *$ & -0.127 & -0.660 & $* * *$ & -0.079 \\
\hline \multicolumn{7}{|l|}{ Job satisfaction: } \\
\hline Satisfied & & & & -0.572 & $* * *$ & -0.042 \\
\hline Very satisfied & & & & -1.147 & $* * *$ & -0.105 \\
\hline Number of observations & 2357 & & & 2357 & & \\
\hline Log likelihood ratio test & 370.37 & $* * *$ & & 443.09 & $* * *$ & \\
\hline Pseudo- $R^{2}(\%)$ & 24.8 & & & 29.66 & & \\
\hline Obs. correctly classified (\%) & 90.9 & & & 91.6 & & \\
\hline
\end{tabular}

${ }^{* * * * * *} / /^{\wedge}$ Significant at the $1 \%, 5 \%, 10 \%$ and $15 \%$ level, respectively.

Source: Own calculations from ECVT (2004).

The following step of our empirical strategy lies in completing our standard econometric model adding job satisfaction variables to the previous specification. Two dummies are introduced, indicating respectively whether the worker is satisfied (from 5 to 7 in the original 
scale) or very satisfied (from 8 to 10) with his current job, being the reference group the one that refers to those who feel unsatisfied (from 1 to 4). Column 2 of Table 3 shows the estimation results. As expected, the estimates for job satisfaction dummies are highly significant, negative, and show the expected order of magnitude: they indicate that the likelihood of on-the-job search is associated negatively with the declared level of satisfaction. This supports the theoretical OJS model outlined in section 2. Also, the introduction of job satisfaction variables considerably improves the goodness of fit of the model (over a 20 percent of increment) and picks up, partially or totally, the impact of some variables for which a significant effect was previously detected (working hours, mismatch in working time/wage combination, commuting time). However, other regressors continue to influence the probability of search after controlling for job satisfaction, indicating that they produce effects on the probability of search not only indirectly through job satisfaction, but in a direct way. Employment stability constitutes the most attractive example. This variable shows an estimated marginal effect of order of magnitude similar to those associated to job satisfaction variables, reflecting the fact that onthe-job search decision has a strong component of preservation against future unemployment situation.

\section{Conclusions}

The negative association between the likelihood of job quit and the previous level of job satisfaction has received profuse empirical interest in the psychological literature and, more recently, in the economic one. In this paper we have analyzed the effect of job satisfaction on a behaviour related to job mobility, that is, on-the-job search. As far as we know, this subject has received no attention in the economic literature. The theoretical on-the-job search models developed assume that individuals behave in such a way as to maximize their expected income stream, so that search is considered exclusively a wage search. The main prediction of the standard theoretical framework is that individuals move toward better-paying jobs.

In section 2 , we outlined a theoretical model in which individuals are assumed to move toward jobs associated with a greater stream of expected lifetime utilities. Workers value new jobs more than the old ones because they are associated to better pecuniary and/or non-pecuniary aspects of work. The main prediction derived from this model is that the likelihood of on-the-job search is negatively related to the worker's level of 
job satisfaction. This model does not seek to deny the relevance of the pecuniary reasons for on-the-job search, but it does seek to explain job searches that are motivated by reasons other than money and may bring a cut in salary but an increase in the stream of expected lifetime utilities.

The econometric analysis presented in section 4 used multivariate analysis techniques to test the main prediction of our model: the existence of a negative relationship between the likelihood of on-the-job search and job satisfaction levels. The determinants of the probability of on-the-job search have been analyzed, assuming that workers choose between to conduct a search or not. The estimates for job satisfaction dummies in the on-the-job search regression are highly significant, negative, and show the expected order of magnitude. So, the likelihood of on-the-job search is associated negatively with the declared level of satisfaction. This finding supports the theoretical OJS model outlined in this paper and confirms the relevant role of job satisfaction in explaining individual behaviours in the labour market.

\section{References}

Akerlof, G. A.; Rose, A. K.; and Yellen, J. L. (1988): "Job switching and job satisfaction in the U.S. labor market", Brooking Papers on Economic Activity, 2, pp. 495-582.

Barron, J. M. and McCafferty, S. (1977): "Job search, labor supply, and the quit decision: Theory and evidence”, American Economic Review, 67, 4, pp. 683-691.

Bartel, A. P. (1982): "Wages, nonwage job characteristics, and labor mobility", Industrial and Labor Relations Review, 35, 4, pp. 578-579.

Benhabib, J. and Bull, C. (1983): "Job search: The choice of intensity", Journal of Political Economy, 91, 5, pp. 747-764.

Burdett, K. (1978): "A theory of employee job search and quit rates", American Economic Review, 68, pp. 212-220.

Clark, A.E. (1997): "Job satisfaction and gender: Why are women so happy at work?", Labour Economics, 4, pp. 341-372.

Clark, A. E.; Georgellis, Y.; and Sanfey, P. (1998): "Job satisfaction, wage changes, and quits: Evidence from Germany", Research in Labor Economics, 17, pp. 95-121. 
Clark, A.E., Oswald, A.J. y Warr, P.B. (1996): "Is job satisfaction U-shaped in age?", Journal of Occupational and Organizational Psychology, 69, pp. $57-81$.

Delfgaauw, J. (2007): "The Effect of Job Satisfaction on Job Search: Not Just Whether, But Also Where", Labour Economics, 14 (3), pp. 299-317.

Dolado, J. J.; Felgueroso, F.; and Jimeno, J. F. (2000): "Youth labour markets in Spain: Education, training, and crowding-out", European Economic Review, 44, pp. 943-956.

ECVT (2004): Encuesta de Calidad de Vida en el Trabajo, Ministerio de Trabajo e Inmigración, Madrid, Spain.

Freeman, R. B. (1978): "Job satisfaction as an economic variable", American Economic Association, Papers and Proceedings, 68, pp. 135-141.

Gamero, C. (2005): Análisis microeconómico de la satisfacción laboral, Colección Estudios, n ${ }^{\circ}$ 171, Madrid: Consejo Económico y Social.

Gamero, C. (2007): "Satisfacción laboral y tipo de contrato en España", Investigaciones Económicas, 31, 3, pp. 415-444.

Gorgens, T. (2002): "Reservation wages and working hours for recently unemployed US women”, Labour Economics, 9, pp. 93-123.

Hughes, G. and McCormick, B. (1985): "An empirical analysis of on-the-job search and job mobility”, The Manchester School, 53, pp. 76-95.

Lancaster, K. L. (1971): Consumer Demand: A New Approach. New York: Columbia University Press.

Lévy-Garboua, L.; Montmarquette, C.; and Simonnet, V. (2001): "Job satisfaction and quits: Theory and evidence from the German Socioeconomic Panel", CIRANO Working Paper, Scientific Series, no 2001s-41.

Mortensen, D. T. (1986): "Job Search and Labor Market Analysis" In Handbook of Labor Economics, II, edited by O. C. Ashenfelter and R. Layard. Amsterdam: North Holland.

PHOGUE (1994-1997): Panel de Hogares de la Unión Europea, Madrid: Instituto Nacinal de Estadística (INE).

Sáez, F. and Rey, R. (2000): "La inserción laboral de los universitarios", Papeles de Economía Española, 86, pp. 99-110.

Seater, J. J. (1979): "Job search and vacancy contacts", American Economic Review, 69, pp. 411-419. 
Shields, M. A. and Ward, M. E. (2001): "Improving nurse retention in the British National Health Service: The impact of job satisfaction on intentions to quit", Journal of Health Eonomics, 20, 5, pp. 677-801.

Souza-Poza, A. and Henneberger, F. (2002): "Analyzing job mobility with job turnover intentions: An international comparative study", 7th Annual Meeting of the Society of Labor Economists (SOLE), Baltimore, 3-4 May.

Van Ophem, H. (1991): "Wages, nonwage job characteristics, and the search behavior of employees", Review of Economics and Statistics, 73, pp. $145-151$.

Van Ours, J. and Ridder, G. (1995): "Job matching and job competition: Are lower educated workers at the back of job queues?", European Economic Review, 39, pp. 1717-1731.

Viscusi, W. K. (1979): "Job hazards and worker quit rates: An analysis of adaptive worker behaviour", International Economic Review, 20, 1, pp. 2958.

Zavoina, W. y McKelvey, W. (1975): "A statistical model for the analysis of ordinal-level dependent variables", Journal of Mathematical Sociology, 4, Summer, pp. 103-120. 


\section{APPENDIX}

Table A.1. Statistical description of variables included in job satisfaction model ${ }^{1}$

\begin{tabular}{|c|c|c|c|}
\hline Variables & Mean & Variables & Mean \\
\hline Job Satisfaction: & & Personal relationships: & \\
\hline Unsatisfied & 0.098 & Good relationships with managers & 0.633 \\
\hline Satisfied & 0.389 & Good relationships with colleagues & 0.818 \\
\hline Highly satisfied & 0.513 & Future prospects: & \\
\hline Individual characteristics: & & Promotion prospects & 0.472 \\
\hline Male & 0.617 & Job mismatch indicators: & \\
\hline \multirow{2}{*}{ Age } & 38.54 & Training mismatch & \\
\hline & $(11.05)$ & Over-training & 0.185 \\
\hline \multirow[t]{2}{*}{$\mathrm{Age}^{\wedge} 2(/ 100)$} & 16.07 & Under-training & 0.022 \\
\hline & $(8.96)$ & Correct training (ref.) & 0.793 \\
\hline Family composition & & Previously unemployed & 0.423 \\
\hline Couple with children & 0.442 & Job tenure (years) & 9.43 \\
\hline Couple without children & 0.185 & & $(10.71)$ \\
\hline Single with children & 0.061 & Job is stable & 0.843 \\
\hline Single without children (ref.) & 0.312 & Other variables: & \\
\hline Education level & & Industry & \\
\hline Less than primary education (ref.) & 0.174 & Agriculture, fishing, etc. & 0.036 \\
\hline Primary Education & 0.221 & Manufacturing industries, etc. (ref.) & 0.182 \\
\hline Lower vocational and technical training & 0.106 & Construction & 0.125 \\
\hline Upper vocational and technical training & 0.095 & Trade and Repairs & 0.122 \\
\hline Upper secondary education & 0.129 & Restaurants, Cafes and Hotels & 0.074 \\
\hline Higher education: medium degree & 0.131 & Transport, communication, etc. & 0.058 \\
\hline Higher education: superior degree & 0.136 & Banking, finance and insurance & 0.030 \\
\hline Others levels & 0.008 & Public Administration and Defence & 0.088 \\
\hline Labour income: & & Education & 0.077 \\
\hline \multirow[t]{2}{*}{ Wage (log. Euros per month) } & 6.91 & Health & 0.071 \\
\hline & $(0.45)$ & Other services & 0.119 \\
\hline Working time: & & Region & \\
\hline \multirow[t]{2}{*}{ Working hours (log. number of hours per month) } & 5.12 & Andalucía (ref.) & 0.126 \\
\hline & $(0.28)$ & Aragón & 0.044 \\
\hline Mismatch in time of work/wage combination: & & Asturias & 0.056 \\
\hline More time and wage & 0.217 & Baleares & 0.050 \\
\hline Less time and wage & 0.248 & Canarias & 0.059 \\
\hline Same time and wage (ref.) & & Cantabria & 0.009 \\
\hline Flexible schedule & 0.112 & Castilla-La Mancha & 0.062 \\
\hline Commuting time: $>45$ minutes & 0.082 & Castilla y León & 0.059 \\
\hline Night work & 0.209 & Cataluña & 0.170 \\
\hline Part-time job & 0.098 & Comunidad Valenciana & 0.090 \\
\hline Job hardness: & & Extremadura & 0.023 \\
\hline Physically demanding & 0.451 & Galicia & 0.044 \\
\hline Stressful & 0.636 & Madrid & 0.084 \\
\hline Pleasant environmental conditions (§) & 0.658 & Murcia & 0.045 \\
\hline Job content/formal communication: & & Navarra & 0.034 \\
\hline Attractive task $(\S)$ & 0.627 & País Vasco & 0.035 \\
\hline Can work independently (§) & 0.507 & La Rioja & 0.021 \\
\hline Helpful for people (§) & 0.614 & & \\
\hline Can give opinions $(\S)$ & 0.552 & & \\
\hline Teamwork & 0.667 & & \\
\hline Supervisor/manager & 0.135 & & \\
\hline Number of observations & 2357 & Number of observations & 2357 \\
\hline
\end{tabular}


Table A.2. Distribution of on-the-job search by personal and job characteristics ${ }^{1}$

\begin{tabular}{|c|c|c|c|}
\hline Variables & $\begin{array}{c}\text { Search } \\
(\%)\end{array}$ & Variables & $\begin{array}{c}\text { Search } \\
(\%)\end{array}$ \\
\hline Job satisfaction & & Training mismatch & \\
\hline Unsatisfied (ref.) & 35.1 & Over-training & 21.7 \\
\hline Satisfied & 11.4 & Under-training & 15.4 \\
\hline Highly satisfied & 3.4 & Correct training (ref.) & 6.6 \\
\hline Male & 8.4 & Previously unemployed & 14.6 \\
\hline Age & & Job tenure (years) & \\
\hline $16-25$ & 16.2 & $<1$ & 21.9 \\
\hline $26-35$ & 13.6 & $1-2$ & 13.5 \\
\hline $36-45$ & 8.1 & $3-4$ & 13.3 \\
\hline $46-55$ & 4.4 & $5-9$ & 6.5 \\
\hline $56+$ & 2.9 & $10+$ & 2.5 \\
\hline Family composition & & Job is stable & 5.6 \\
\hline Couple with children & 6.3 & Industry & \\
\hline Couple without children & 9.4 & Agriculture, fishing, etc. & 14.0 \\
\hline Single with children & 11.2 & Manufacturing industries, etc. (ref.) & 8.6 \\
\hline Single without children (ref.) & 14.1 & Construction & 8.8 \\
\hline Education level & & Trade and Repairs & 11.1 \\
\hline Less than primary education (ref.) & 7.8 & Restaurants, Cafes and Hotels & 12.0 \\
\hline Primary Education & 8.4 & Transport, communication, etc. & 9.6 \\
\hline Lower vocational and technical training & 10.0 & Banking, finance and insurance & 7.1 \\
\hline Upper vocational and technical training & 9.3 & Public Administration and Defence & 7.2 \\
\hline Upper secondary education & 9.9 & Education & 7.7 \\
\hline Higher education: medium degree & 11.0 & Health & 7.8 \\
\hline Higher education: superior degree & 12.5 & Other services & 12.9 \\
\hline Others levels & 5.0 & Region & \\
\hline Wage (euros) & & Andalucía (ref.) & 7.1 \\
\hline$<450$ & 28.1 & Aragón & 4.8 \\
\hline $451-900$ & 14.8 & Asturias & 14.3 \\
\hline $901-1205$ & 7.2 & Baleares & 12.6 \\
\hline $1206-1655$ & 4.3 & Canarias & 10.1 \\
\hline $1656+$ & 3.5 & Cantabria & 7.0 \\
\hline Weekly hours of work & & Castilla-La Mancha & 6.9 \\
\hline$<15$ & 12.9 & Castilla y León & 8.6 \\
\hline $15-29$ & 17.9 & Cataluña & 9.5 \\
\hline $30-39$ & 8.3 & Comunidad Valenciana & 7.6 \\
\hline $40-49$ & 8.8 & Extremadura & 14.5 \\
\hline $50+$ & 11.1 & Galicia & 11.7 \\
\hline Mismatch in time of work/wage combination: & & Madrid & 16.2 \\
\hline More time and wage & 16.0 & Murcia & 6.7 \\
\hline Less time and wage & 9.1 & Navarra & 5.1 \\
\hline Same time and wage (ref.) & 7.3 & País Vasco & 11.0 \\
\hline Commuting time: $>45$ minutes & 18.1 & La Rioja & 10.0 \\
\hline Total & 9.6 & Total & 9.6 \\
\hline Number of observations & 2357 & Number of observations & 2357 \\
\hline
\end{tabular}

